\title{
The Effect of Capital Structure on Financial Performance with Firm Size as a Moderating Variable of Non-Financial Firms Listed at the Nairobi Securities Exchange
}

\author{
Kerongo Meshack, \\ Winnie Nyamute, \\ Kennedy Okiro, \\ Elly Duncan, \\ Department of Finance and Accounting, School of Business, \\ University of Nairobi, Kenya
}

Doi:10.19044/esj.2020.v16n22p139 URL:http://dx.doi.org/10.19044/esj.2020.v16n22p139

\begin{abstract}
This paper examines the effect of capital structure on the financial performance of the non-financial firms listed at the Nairobi Securities Exchange and how this relationship is moderated by firm size. In addition, the paper evaluates the existence of equilibrium and disequilibrium relationship among the variables. The study analyzed unbalanced panel data sourced from across 53 non-financial firms listed at the Nairobi Securities Exchange which covers the period from 2010 to 2017 . Total debt to total equity, total equity to total assets, and total debt to total assets were used for assessing capital structure of the listed non-financial firms. Firm size was measured using natural logarithm of total sales. Financial performance attribute was measured by Tobin's Q. Data was analyzed using descriptive statistics, multiple and simple regression analysis. Regression analysis was used to ascertain the direction and magnitude of the relationships. The study revealed that leverage had a significant positive effect on the financial performance of the NSE listed non-financial firms. Furthermore, firm size has a positive moderating effect on the relationship between capital structure and financial performance. The study concludes that firms should strive to increase their leverage since it has a statistically significant positive effect on financial performance of the nonfinancial firms listed on the NSE. The study further concludes that firms should strive to grow their firm size by increasing their total sales. This is because it has a statistically significant positive effect on the financial performance of NSE listed non-financial firms.
\end{abstract}


Keywords: Financial performance, Tobin's Q, Capital structure, Firm Size, Multiple regression analysis

\section{Introduction}

Capital structure is an intensely controversial issue in finance (Myers, 2001). According to the Modigliani and Miller (1958) theorem, a firm's level of debt or equity is inconsequential from an economic point of view. This is due to the corporate tax shield resulting from debt financing and increased cost of equity. High cost of equity leads to increased cost of capital. In their research, Modigliani and Miller evaluated two firms with varying capital structures, one having debt in its capital structure while the other firm's capital structure constituted no debt. The authors concluded that the firm's financial performance is not determined by the financial decisions taken by companies and the market value. Ideally, Modigliani and Miller speculate that the forecasted cash flow is divided adequately between the firm's investors as per the capital structure while the company's value is not influenced by this shareout.

However, this dimension has, however, been opposed through several studies which argue that debt levels possess non-neutral impacts on the performance and behaviour of the firm. Kosimbei et al. (2014) argued that corporate failure in Kenyan firms often had a connection with the behaviour of financing in these firms. Great focus has been on the failing companies that have undergone restructuring in their firm financing. Dilemma exists on the possibility of firms attaining an optimal capital structure, both short-term and long-term. This optimal capital structure and its effect on financial performance is also a matter under consideration. According to Harris (2017), higher firm performance is realized at higher levels of debt. Increased leverage leads to tax exclusion on interest paid on debt. This directly influences the firms' profitability and its financial performance. Simerly and Li (2000), on the contrary, stated the debt presence in the firm and how it causes decreased financial performance. This is due to increased cost of equity that causes an increase in the cost of capital, which ultimately causes a decline in the firms' financial performance.

The financial performance of non-financial firms is likely to be influenced by firm size. This indicates that firm size influences capital financing decisions embraced by a firm. Wahome et al. (2015) indicate that the use of leverage in financing operations is more common among large firms compared to small ones. Among the reasons identified for limited use of leverage among small firms include asymmetric information (adverse selection), higher bankruptcy costs, huge costs of resolving informational asymmetries, and greater agency costs. Dogan (2013) argues that a positive 
significant relationship exists between indicators of firm size such as total assets, total sales, and numbers of employees with firms' profitability. Firm size has a strong moderating effect on financial distress and capital structure relationship of non-financial firms. This is premised on the notion companies that are small in size are highly disadvantaged compared to the bigger ones. Firms that are bigger tend to have economies of scale. Thus, these companies have a bigger scope of operation and possess a bargaining power that is stronger. In addition, bigger companies are more profitable than smaller companies (Mugai \& Muriithi, 2017). Studies that have examined financing among corporates have nevertheless indicated that whenever the company value grows, there is a commensurate decline in direct bankruptcy costs to the company value. The impact of these costs associated with bankruptcy is likely to manifest less in smaller companies than in bigger companies' decisions on borrowing, which strengthens their capability to be highly leveraged (Rajan \& Zingales, 2005). On the flip side, companies that are smaller tend to deal with the realities of obtaining long term debt. The main reason is not information asymmetry, but the probability of bankruptcy and firm size's significant negative correlation with long term debt. Large companies are more diversified and are not exposed to insolvency. Chittenden et al. (2006) contends that among firms that are large, borrowing costs manifest lesser when compared to their smaller competitors. Their argument is based on problems of moral hazard and adverse selection that decline greatly among firms that are large. Consequently, external funding that involves employment of debt in companies that are large and listed is more beneficial than in SMEs. Therefore, there is a positive relationship between firm size and the level of debt (Ozkan, 2001).

Furthermore, the role of the size of the company is critical in determining its capital structure (Abor \& Biekpe, 2006). Firm size' importance as a moderating variable has been routinely employed in corporate empirical studies in finance. Several reasons that are theoretically based have been suggested on capital structure and size of the firm relationship. These reasons include the lowering of the asymmetry of information through the use of economies of scale, access to markets, and costs of transactions. Bigger firms tend to have a form diversification of their sources of financing. Firm size may also be a proxy for the default probability because of the contention that companies that are bigger cannot easily fall and be liquidated (Duffie, 2005). Firm size may also be a proxy for the volatility of firm assets. This is because firms that are small tend to be those that are growing. The other explanation is the extent of distortion in the level of information asymmetry in capital markets and among insiders which may be reduced for bigger companies because investors who are ever-suspicious tend to examine them more closely (Fama \& French, 2002). 
Firm size is very significant in determining firm financial performance. Firm size is deemed to promote and grow firm financial performance (Dogan, 2016). Firm size can cause inferior performance because of market inefficiencies and formalized procedures. Larger companies can also attract exemplary human resources that will significantly contribute to their financial performance. Bigger companies face less bankruptcy risk since they undertake massive diversification as compared to smaller ones. Consequently, reduced bankruptcy empowers bigger companies to finance their operations using more debts. Among other benefits accrued by larger firms is low level of information asymmetries and ease in obtaining financial resources which causes increased performance (Gonenc, 2005).

\section{Statement of the Problem}

Despite many interventions, several inadequacies in choices of capital structure and financial performance problems among some non-financial firms have been witnessed in Kenya. This has resulted to companies facing receivership/statutory management, hostile takeovers, and government bailout. According to Onyango et al. (2016), increased leverage in firms leads to increased financial performance. Furthermore, decreased leverage causes financial performance to decline. This gives an indication of differences in causal relationship between equity financing and debt financing on companies that are listed on financial performance. Firms that are highly leveraged and that were considered big such as Kenya Airways, Home Africa, ARM cement, and Transcentury have experienced great losses, fallen into deep depth owing debts more than their net worth. These firms had relied much on debt financing which tends to be more liquid in order to pay their debt obligations. This led to decreased financial performance. Firm size influences the financing decisions of firm managers by encouraging them to utilize more debt than equity in order to grow the company's performance. This is due to the interest tax advantage obtained as a result of debt financing. On the contrary, Heshmati (2008) argued that companies that are listed and tend to be big have easy access to the equity market compared to firms that are smaller in size due to low fixed costs. Consequently, debt level and firm size have a negative relationship.

Fama and Jensen (2003) opine that big companies like to seek funding from equity rather than debt sources. This is due to the higher costs of transactions and information asymmetry that are less manifested in big companies in comparison with small ones. Small firms also face shortcomings in accessing external financing (Cassar \& Holmes, 2003). This, therefore, raises the moderating contribution of firm size in the non-financial firms' financial performance and capital structure relationship. Consequently, company managers are unable to decipher the contribution that capital 
structure has on the companies' financial performance (Kamuti \& Omwenga, 2017). The inability of firm managers to make choices on capital structure can be linked to the difficulties in ascertaining the debt and equity that is optimal in their companies that can help increase financial performance (Noreen, 2013). Firm size's moderating contribution in the financial performance and capital structure relationship of the listed non-financial firms also adds to the challenge that firm managers grapple with in seeking to improve the listed non-financial firms' financial performance. This study seeks to answer the question: What is the moderating role of firm size on the relationships between capital structure and financial performance of the NSE listed non-financial firms?

\section{Research Objective}

The objective of this paper is to determine the effect of firm size on the relationship between capital structure and the financial performance of nonfinancial firms listed at the Nairobi Securities Exchange. Specifically, it aims to:

a) determine the effect of capital structure on the financial performance of non-financial firms listed at the Nairobi Securities Exchange;

b) determine the moderating effect of firm size on the relationship between capital structure and financial performance of non-financial firms listed at the Nairobi Securities Exchange.

\section{Literature Review}

Rayan (2010) did a 10-year longitudinal study of 113 companies listed in the Johannesburg Stocks Exchange, South Africa, with a view to ascertain the financial leverage and firm value relationship. Debt-equity ratio was used as a construct for financial leverage while ROE, ROA, EPS, and P/E ratio were used to proxy firm value. The study found a negative correlation between the use of debt in relation to equity and all measures of firm value. Thus, the result of the study increased leverage and decreased firm value among the Southern African firms. The author attributed this negative relationship to excessive use of debt financing by firms so as to make gain due to shields emanating from tax. Firm size's moderating effect and the intervention effect of liquidity were not conducted. Subsequently, the study was focused on the companies on the Johannesburg Stocks Exchange. A similar study should be done focusing on companies that are listed on the NSE.

Wahome et al. (2015) studied the risk and firm size impact on the decisions regarding capital structure among the Kenyan insurance firms using the panel regression model. Leverage in financing operations was more common among large insurance entities compared to small ones. Among the reasons identified for limited use of leverage among small firms include 
asymmetric information (adverse selection), higher bankruptcy costs, huge costs of resolving informational asymmetries, and greater agency costs. The study focused on the insurance sector in isolation of firms operating in other sectors such as the manufacturing sector. The study was also done for a shorter period of time. However, a longer period of time should have been considered. Dogan (2013), by the use of correlation analysis and multiple regression, investigated firm size's impact on profitability. Data of 200 firms that were present in the Istanbul Stock Exchange (ISE) in the year 2008-2011 was used. Firm profitability was operationalized by ROA. Natural log of total assets, natural $\log$ of total sales, and natural log of numbers of employees were used to operationalize firm size. The indication of the study is that a positive relationship exists between profitability of firms and firm size indicators. The study did not take capital structure into consideration. Furthermore, liquidity as an intervening variable was not considered in the study.

\section{Conceptual Framework}

Based on the theoretical and literature review, the following conceptual model guided the study as presented in Figure 1. The figure below shows that the relationship could be influenced by capital structure and moderated by firm size as shown by the arrow representation.

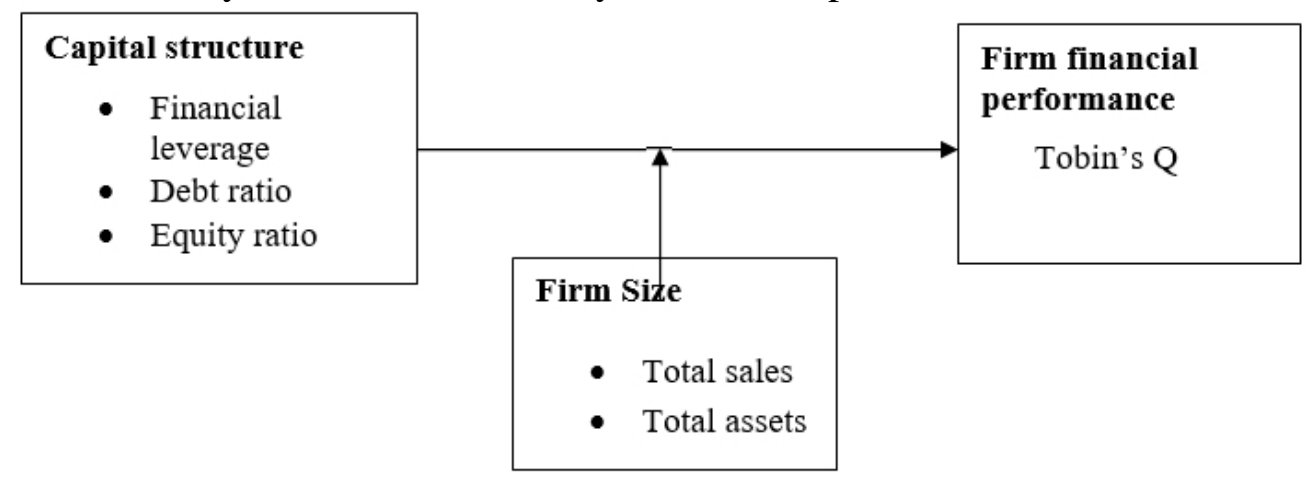

Figure 1. Conceptual model and hypothesis

Based on the research objectives, the study developed the following nullhypothesis:

$\mathrm{H}_{1}$ : There is no relationship between capital structure and financial performance of the NSE listed non-financial firms.

$\mathrm{H}_{2}$ : The relationship between capital structure and financial performance of the NSE listed non-financial firms is not moderated by firm size.

\section{Data and Methodology}

Quantitative secondary data on the study variables was obtained from the NSE website. Data on capital structure was determined by obtaining debt and equity employed by the listed non-financial companies in their various 
operations. The book values of total equity and total assets were employed to determine the listed non-financial companies' financial performance. Firm size was determined by total assets and total sales. Total assets can be operationalized by natural logarithm of total assets, and total sales can be operationalized by natural logarithm of total sales. Secondary data on capital structure and financial statements was used because it gives reliable results as compared to primary data. Secondary data was mainly a seven-year (20102017) annual historical data on the listed firms' financial performance. A census survey was conducted since the size of the population is small. There are a total of fifty-three (53) non-financial companies on the NSE listing as at $31^{\text {st }}$ December, 2017. The study period 2010 to 2017 was chosen because many non-financial firms faced financial distress, bankruptcies, and takeovers. Analysis of data was done through the use of descriptive analysis. Regression analysis was also done to determine the nature and magnitude of the relationships between the study variables and to test the relationships that were hypothesized. Pearson's correlation analysis was done to ascertain the degree of the linear relationship among the variables.

To determine the relationship between capital structure and financial performance (objective $\mathrm{i})$, hypothesis $\left(\mathrm{H}_{1}\right)$, the following model was used; $\mathbf{Y}=\boldsymbol{\beta}_{0}+\boldsymbol{\beta}_{1} \mathbf{X}_{1}+\varepsilon$ 3.1

$\mathrm{Y}=$ Firm financial Performance,

$\mathrm{B}_{0}=$ intercept, $\mathrm{X}_{1}=\mathrm{CS}, \beta_{1}, \beta_{2}, \beta_{3}, \beta_{4}=$ coefficients, $\varepsilon=$ Error term

Where $\mathrm{Y}$ and $\mathrm{CS}$ are vectors for firm financial performance and capital structure, respectively.

Multiple regression model was employed to make a determination of the moderating effect (objective ii) of firms size in concurrence with the methodology by Baron and Kenny (1986). The second hypothesis $\left(\mathrm{H}_{2}\right)$ was done by the following model;

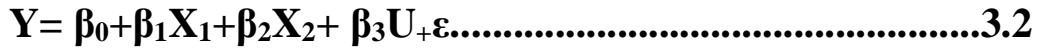

$Y=$ Firm financial Performance,

$\mathrm{B}_{0}=$ intercept, $\mathrm{X}_{1}=\mathrm{CS}, \mathrm{X}_{2}=$ Firm Size, $\beta_{1}, \beta_{2}, \beta_{3}=$ coefficients, U=interaction term of Capital Structure \& Firm Size= Error term

Where $\mathrm{Y}$ and CS are vectors for financial performance and capital structure, respectively.

\section{Diagnostic Tests}

Correlation analysis was done to determine whether the variables had a linearly relationship. The null hypothesis for the test shows that there is no linear relationship. The test statistic for linear relationship between the 
predictor variable and firm financial performance (explanatory variable) are shown in Table 1 below.

Table 1. Test for Linearity

\begin{tabular}{|l|c|l|}
\hline $\begin{array}{l}\text { Reference Variable: Firm } \\
\text { Performance }\end{array}$ & Coefficient of Correlation & P-Value \\
\hline Capital structure & 0.506 & 0.000 \\
\hline Firm size & 0.619 & 0.000 \\
\hline \multicolumn{2}{|l}{ Source: Research Data 2020 }
\end{tabular}

From Table 1, capital structure indicates a coefficient of correlation of 0.506 and firm size shows a coefficient of 0.619 . The values exceed 0.5000 which means that a positive correlation exists. The respective coefficient of correlation p-value is 0.000 which is lower than 0.05 . Thus, capital structure has a significant positive correlation with financial performance at five percent level of significance. Therefore, the predictor variables and the explanatory variable move in the same direction which suggests a linear relationship. This positive correlation indicates that the signage coefficient of the predictor variables in the simple regression model is positive.

To test the level of multicollinearity that would be tolerated in the models estimated, VIF of less than 10 indicates tolerable levels of multicollinearity (Robinson \& Schumacker, 2009). Multicollinearity test finds applications only in multivariate regressions. Also, VIF statistics are the only ones reported because the regressions have more than one independent variable.

Table 2. Test for multicollinearity

\begin{tabular}{|l|l|}
\hline Variables & VIF \\
\hline Capital structure & 2.09 \\
\hline Financial Performance & 3.09 \\
\hline Firm Size (Total sales) & 2.42 \\
\hline
\end{tabular}

Source: Research Data 2020

Table 2 shows that the VIF for all models are between the acceptable ranges of 1.45 to 3.09.This indicates that the results of the VIF are between the ranges of 1 to 10 (Robinson \& Schumacker, 2009). Also, this indicates that multicollinearity was not exhibited by the variables. Therefore, regression analysis could be carried out. When the VIF factor $>10$, it would imply serious multicollinearity. Serious multicollinearity can be dealt with by dropping collinear variables or obtaining additional data.

\section{Hypothesis Testing and Discussions Descriptive Statistics}

In order to visualize the dataset, descriptive statistics were generated as shown in Table 3. 
Table 3. Descriptive Statistics

\begin{tabular}{|c|r|r|r|r|r|r|}
\hline & \multicolumn{1}{|c|}{$\mathrm{N}$} & \multicolumn{1}{|c|}{ Minimum } & Maximum & \multicolumn{2}{|c|}{ Mean } & Std. Deviation \\
\cline { 2 - 7 } & Statistic & Statistic & Statistic & Statistic & Std. Error & \multicolumn{1}{c|}{ Statistic } \\
\hline CS & 233 & .50 & 3.00 & 1.8382 & .03597 & .54902 \\
FP & 233 & .04 & 6.00 & 3.4686 & .09738 & 1.48641 \\
Valid N (listwise) & 233 & & & & & \\
\hline
\end{tabular}

Source: Research Data 2020

The results presented in Table 3 above shows descriptive statistics for secondary data for a 7-year period from 2010 to 2017. Table 1 gives the descriptive for the main research study variables. The table shows that the average Tobin's Q is 3.4686. This indicates that, averagely, NSE listed companies have a fairly impressive financial performance. The Tobin's Q mean of 3.4686 suggests that the firm's market values are more than the firms' book values. The market price to book value ratio, being more than one, means that the market value expectation of these companies will increase. This is because the future earnings are taken into account using the current price. The average for capital structure is 1.8382 , meaning that most NSE listed nonfinancial companies have a large debt amount as compared to equity.

\section{Pearson Moment Correlations between Financial Performance and Capital Structure}

The strength and direction of the variables' relationship was investigated. This was done using correlation coefficient. This was crucial in making an assessment as to whether any relationship exists between the variables before proceeding with further analysis. The study employed the following classification: strong if 0.7 and above, moderate if 0.4 but less than 0.7 , and weak if 0 and less than 0.4 .

Apart from analyzing the direction and strength of the relationship, correlation analysis was also used to find out the existence of multicollinearity. Multicollinearity exists if the independent variables are highly correlated ( $\mathrm{r}=\mathrm{or}$ greater than 0.75). Multicollinearity reduces the importance of predictors, making it difficult to assess the individual importance of a predictor. Multicollinearity may lead to poor regression modeling (Dancey \& Reid, 2011). The results in Table 4 below show that there is no multicollinearity since all the predictor coefficient results are below 0.75 . 
Table 4. Correlations

\begin{tabular}{|rc|r|r|r|r|r|r|}
\hline & & \multicolumn{1}{c|}{ CS } & ASSETLQ & TEMPINV & SALES & ASSETS & \multicolumn{1}{c|}{ FP } \\
\hline \multirow{2}{*}{ CS } & Pearson Correlation & 1 & $.444^{* *}$ & $.436^{* *}$ & -.045 & $.822^{* *}$ & $.769^{* *}$ \\
& Sig. (2-tailed) & & .000 & .000 & .494 & .000 & .000 \\
& Pearson Correlation & $.769^{* *}$ & $.545^{* *}$ & $.443^{* *}$ & .012 & $.940^{* *}$ & 1 \\
\multirow{2}{*}{ FP } & Sig. (2-tailed) & .000 & .000 & .000 & .858 & .000 & \\
& $\mathrm{~N}$ & 233 & 233 & 233 & 233 & 233 & 233 \\
& & & &
\end{tabular}

**. Correlation is significant at the 0.01 level (2-tailed).

Source: Research Data 2020

As shown in Table 4 above, a strong positive correlation exists between financial performance and capital structure $(r=0.769)$. Financial performance and capital structure relationship moved in the same direction as hypothesized in the study.

\section{Regression of Capital Structure and Financial Performance}

The study resorted to determine the effect of capital structure and financial performance of the NSE listed nonfinancial firms and it employed panel data design. Panel data was used in establishing financial performance which was measured by Tobin's Q. Debt/equity ratio was used to measure capital structure. The study sought to identify the effect of capital structure on financial performance. The following hypothesis was developed:

$\mathbf{H}_{1:}$ Capital structure has no effect on the financial performance of nonfinancial firms listed on the NSE. Maximum Likelihood Regression Model was employed in data analysis. Test statistic regression results with the dependent variable and the independent variable are reported in Table 5 below:

Table 5. Panel data results for capital structure and financial performance

Model Summary

\begin{tabular}{|c|r|r|r|c|}
\hline Model & R & R Square & $\begin{array}{c}\text { Adjusted R } \\
\text { Square }\end{array}$ & $\begin{array}{c}\text { Std. Error of the } \\
\text { Estimate }\end{array}$ \\
\hline 1 & $.769^{\mathrm{a}}$ & .591 & .590 & .95216 \\
\hline & & & & \\
\hline
\end{tabular}

a. Predictors: (Constant), CS

Table 6. ANOVA

\begin{tabular}{|c|c|c|c|c|c|c|}
\hline & Model & Sum of Squares & df & Mean Square & $F$ & Sig. \\
\hline \multirow{3}{*}{1} & Regression & 303.160 & 1 & 303.160 & 334.389 & $.000^{\mathrm{b}}$ \\
\hline & Residual & 209.427 & 231 & .907 & & \\
\hline & Total & 512.587 & 232 & & & \\
\hline
\end{tabular}

a. Dependent Variable:

b. Predictors: (Constant), CS 
Table 7. Regression Coefficients

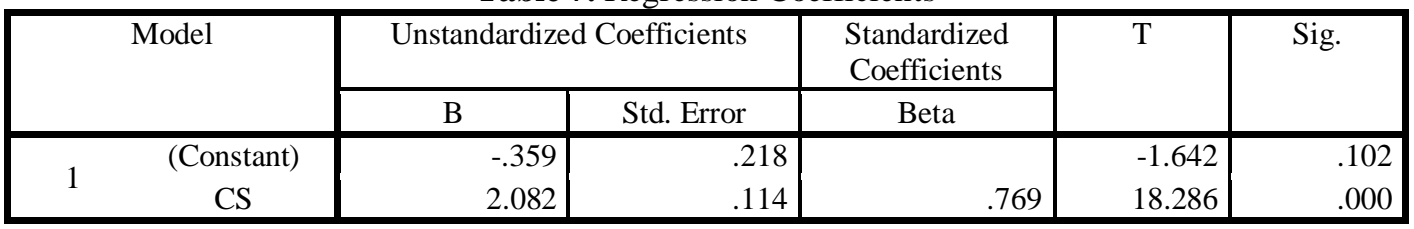

a. Dependent Variable: FP

b. Predictors: (Constant), CS

Source: Research Data 2020

The coefficients in the model are shown in Table 7 above. The study results show that capital structure is a significant predictor because the $\mathrm{p}$-value is 0.000 .This is lesser than 0.05 (level of significance). Furthermore, the results indicate $\mathrm{R}^{2}$ of 0.591 which implies that capital structure explains $59.1 \%$ of the variability in financial performance. The null hypothesis has been accepted giving the implication that capital structure has an effect that is significant on financial performance of nonfinancial firms listed at the NSE as shown below:

$\mathrm{Q}_{\mathrm{it}=-0.359+2.082 \mathrm{CS}_{\mathrm{it}}}$

Where:

$\mathrm{Q}=$ Financial Performance

$\mathrm{CS}=$ Capital Structure

\section{Capital Structure, Firm Size, and Financial Performance}

This study resorted to determine the effect of firm size on the relationship between capital structure and financial performance with the hypothesis.

The moderating effect of firm size on relationship between capital structure and financial performance was assessed using the centred approach by $\mathrm{Wu}$ and Zumbo (2008). This involves the following two steps. Step 1 involves the independent variables and the moderator variables being regressed against financial performance. Step 2, on the other hand, entails introduction of the centred approach in the model with the predictor, moderating variable, and interaction term being factored. Results of the regression results are shown below in Table 8 .

Panel Data Results for Financial Performance as Dependent Variable and Capital structure and Firm Size (Total Sales) as the predictor variables

Table 8. Model Summary

\begin{tabular}{|c|r|r|r|r|}
\hline Model & R & R Square & Adjusted R Square & Std. Error of the Estimate \\
\hline 1 & $.770^{\mathrm{a}}$ & .594 & .590 & .95171 \\
\hline
\end{tabular}

a. Predictors: (Constant), SALES, CS

b. Dependent Variable: FP 
Table 9. ANOVA

ANOVA $^{\mathrm{a}}$

\begin{tabular}{|c|c|c|c|c|c|c|}
\hline \multicolumn{2}{|r|}{ Model } & Sum of Squares & $\mathrm{df}$ & Mean Square & $\mathrm{F}$ & Sig. \\
\hline \multirow{3}{*}{1} & Regression & 304.265 & 2 & 152.132 & 167.964 & $.000^{\mathrm{b}}$ \\
\hline & Residual & 208.322 & 230 & .906 & & \\
\hline & Total & 512.587 & 232 & & & \\
\hline
\end{tabular}

a. Dependent Variable: FP

a. Predictors: (Constant), SALES, CS

Table 10. Coefficients ${ }^{\mathrm{a}}$

\begin{tabular}{|c|c|c|c|c|c|c|}
\hline & \multirow[t]{2}{*}{ Model } & \multicolumn{2}{|c|}{ Unstandardized Coefficients } & \multirow{2}{*}{$\begin{array}{c}\text { Standardized } \\
\text { Coefficients } \\
\text { Beta }\end{array}$} & \multirow[t]{2}{*}{$\mathrm{T}$} & \multirow[t]{2}{*}{ Sig. } \\
\hline & & $\mathrm{B}$ & Std. Error & & & \\
\hline \multirow{3}{*}{1} & (Constant) & -.580 & .297 & & -1.957 & .052 \\
\hline & $\mathrm{CS}$ & 2.088 & .114 & .771 & 18.326 & .000 \\
\hline & SALES & .057 & .051 & .046 & 1.104 & .271 \\
\hline
\end{tabular}

a. Dependent Variable: FP

b. Predictors: (Constant) SALES, CS

Source: Research Data 2020

Results in Table 8 above show $\mathrm{R}^{2}$ of 0.594 and adjusted $\mathrm{R}^{2} 0.590$. Table10 above show the coefficients of capital structure and total sales as 2.088 and 0.057 , respectively. The $\mathrm{p}$ values for capital structure and total sales are 0.000 and 0.271 respectively, indicating statistical significance for capital structure because the $\mathrm{p}$ value is less than 0.05 . For sales, the $\mathrm{p}$ value is greater than 0.05 which indicates statistical insignificance. Results for step 2 are displayed in Table 11 below, where the interaction term is introduced.

Table 11. Panel Data Results for Financial Performance as the Dependent Variable, Capital

Structure and firm size (Total Sales) as the Predictor Variables, Centered Approach

Model Summary

\begin{tabular}{rr|r|c|r|r} 
Model & R & R Square & $\begin{array}{c}\text { Adjusted R } \\
\text { Square }\end{array}$ & $\begin{array}{c}\text { Std. Error of the } \\
\text { Estimate }\end{array}$ & Durbin-Watson \\
\hline 1 & $.777^{\mathrm{a}}$ & .604 & .599 & .94143 & .192 \\
\hline
\end{tabular}

a. Predictors: (Constant), CS_SALES_CENTRED, CS_CENTRED, SALES_CENTRED

Table 12. ANOVA

\begin{tabular}{llr|r|r|r|r} 
& Model & Sum of Squares & df & Mean Square & F & \multicolumn{1}{c}{ Sig. } \\
\hline \multirow{2}{*}{1} & Regression & 309.627 & 3 & 103.209 & 116.451 & $.000^{\mathrm{b}}$ \\
\cline { 2 - 8 } & Residual & 202.960 & 229 & .886 & & \\
\hline & Total & 512.587 & 232 & & & \\
\hline
\end{tabular}

a. Dependent Variable: FP

b. Predictors: (Constant), CS_SALES_CENTRED, CS_CENTRED, SALES_CENTRED 
Table 13. Coefficients

\begin{tabular}{|c|c|c|c|c|c|c|}
\hline \multirow[b]{2}{*}{ Model } & & \multicolumn{2}{|c|}{ Unstandardized Coefficients } & \multirow{2}{*}{$\begin{array}{l}\text { Standardized } \\
\text { Coefficients } \\
\text { Beta }\end{array}$} & \multirow[b]{2}{*}{$\mathrm{t}$} & \multirow[b]{2}{*}{ Sig. } \\
\hline & & $\mathrm{B}$ & Std. Error & & & \\
\hline \multirow[t]{4}{*}{1} & (Constant) & 3.479 & .062 & & 56.274 & .000 \\
\hline & CS_CENTRED & 2.211 & .123 & .817 & 17.930 & .000 \\
\hline & SALES_CENTRED & -.035 & .063 & -.028 & -.550 & .583 \\
\hline & CS_SALES_CENTRED & .358 & .146 & .136 & 2.460 & .015 \\
\hline
\end{tabular}

a. Dependent Variable: FP

b. Predictors: (Constant), CS_SALES_CENTRED, CS_CENTRED, SALES_CENTRED

Source: Research Data 2020

Results from Table 11 above revealed that $\mathrm{R}$ squared show change from 0.594 to 0.604 , which is a change of 0.1 ( $10 \%$ change). Adjusted $\mathrm{R}$ squared changed from 0.59 to 0.599 which is a change of 0.009 ( $0.9 \%$ change) occasioned by the interaction term. This is also confirmed by the $\mathrm{p}$ values which are less than 0.05 . This means firm size (total sales) moderates the relationship between capital structure and financial performance significantly. The regression model for the moderation effect of total sales is shown below: $\mathrm{Q}_{\text {it }}=3.479+2.211 \mathrm{CS}_{\text {it }}+-.035$ SALES $_{\text {it }}+0.358$ CS SALES $_{\text {it }}$

\section{Discussion}

The first objective of the research was to determine the influence of capital structure on financial performance of NSE's listed non-financial firms. This was achieved by analyzing the panel data. The indication from the results is that a significant positive relationship exists between capital structure and financial performance. These studies are consistent with other similar ones. For example, Saeedi and Mahmoodi (2011) found a relationship that is positive between capital structure and financial performance of firms listed at the Teheran Securities Exchange. The positive significant effect of capital structure on financial performance is due to increased level of leverage by the firms. This leads firms to utilize a greater amount of debt thereby obtaining the debt tax benefits. Consequently, these tax benefits lead to increased profitability and financial performance. Similarly, Cyril (2016) established that capital structure has an effect on both ROA and AT of the conglomerates but did not find any effect on return on equity (ROE) and earnings per share (EPS) of the conglomerates. The study difference based on the study findings by Cyril (2016) are due to business factors which affect a particular industry depending on where the firm operates. This is due to the different tax benefits obtained in the debt-equity mix in various industry sectors. Furthermore, differences in the study findings are due to differences in the operationalization of financial performance between the accounting and market based measures. The study indicates that use of leverage in financing operations is more common among large firms compared to small ones. 
Among the reasons for limited use of leverage among small firms include asymmetric information (adverse selection), higher bankruptcy costs, huge costs of resolving informational asymmetries, and greater agency costs. The study findings therefore indicate that firm size exhibits a statistically significant positive moderating effect on the relationship between capital structure and financial performance. Thus, the effect is statistically significant. The positive effect of firm size is confirmed by Mugai and Muriithi (2017) who asserts that firm size has a strong moderating effect on the relationship between capital structure and the financial distress of nonfinancial firms. The indication from this study is that larger companies report increased profitability in comparison to smaller ones. Similarly, Abbasi (2015) found out that firm size has a moderating effect on the relationship between firm growth and performance in Pakistan. The findings from the study show that increases in firm size leads to a commensurate growth in company profitability. This is because big firms can attract exemplary human resources that will significantly contribute to their financial performance.

Big companies can gain as a result of economies of scale, scope of operation, and stronger bargaining power. Consequently, smaller firms are less profitable than bigger firms. Companies that are relatively bigger have a tendency of embracing diversification. Also, they have fewer insolvency risks. Larger firms can also attract exemplary human resources that will significantly contribute to their financial performance. Large companies face fewer bankruptcy risks since they undertake massive diversification as compared to companies that are smaller. Low bankruptcy levels assist companies that are big to have increased profitability. Similarly, Wahome et al. (2015) studied the effects of risk and firm size on the decisions regarding capital structure among the Kenyan insurance companies. Results from the research indicated that the use of leverage in financing operations in big insurance companies is more apparent as compared to those that are smaller and this led to increased companies' profitability. Among the reasons identified for limited use of leverage among small firms include asymmetric information (adverse selection), higher bankruptcy costs, huge costs of resolving informational asymmetries, and greater agency costs. From the study findings, the increase in financial performance as a result of increase in firm size is due to the reason that big companies do not face increased bankruptcy even with increased leverage levels since they undertake massive diversification as compared to smaller companies. This massive diversification helps in risk mitigation that leads to growth in profitability of the listed nonfinancial firms.

\section{Summary of Findings}

This research was premised on capital structure affecting financial performance. The first objective of the research was to determine capital 
structure and financial performance relationship among NSE listed nonfinancial companies. Capital structure has a statistically significant effect that is positive on the financial performance of the nonfinancial firms listed on the NSE. The findings are supported by a coefficient of 59.1 which indicates that the explanatory variable and financial performance is elucidated by capital structure and predictor variable. The effect of capital structure was established to be significant statistically. Therefore, this leads to the rejection of the null hypothesis.

Subsequently, findings on the effect of capital structure on financial performance also showed a statistically significant relationship. These studies are consistent with other studies on capital structure and financial performance. For example, Saeedi and Mahmoodi (2011) obtained a positive relationship between capital structure and financial performance of listed companies at the Teheran Securities Exchange. A positive significant effect of capital structure on financial performance is due to increased level of leverage by firms. This leads firms to utilize increased amount of debt thereby obtaining the tax benefits associated with debt financing. Consequently, the tax benefits lead to increased profitability and financial performance.

Similarly, Cyril (2016) established that capital structure has an effect on both ROA and AT of the conglomerates but has no effect on ROE and EPS of the conglomerates. The study difference based on the study findings by Cyril (2016) are due to business factors which affect a particular industry depending on the industry where the firm operates. This is due to the different tax benefits obtained in the debt-equity mix in various industry sectors. Furthermore, differences in the study findings are due to differences in the operationalization of financial performance between the accounting and market based measures.

The study indicates that the use of leverage in financing operations is more common among large firms as compared to small ones. Among the reasons identified for limited use of leverage among small firms include asymmetric information (adverse selection), higher bankruptcy costs, huge costs of resolving informational asymmetries, and greater agency costs. The study findings therefore indicate that firm size exhibits a statistically significant positive moderating effect on the relationship between capital structure and financial performance, and the effect is statistically significant. The positive effect of firm size is given a confirmation by Mugai and Muriithi (2017) who determined that firm size has a strong moderating effect on capital structure and the financial distress of the nonfinancial firms' relationship. This indicates that larger firms report higher financial performance and tend to face a higher financial distress in comparison to smaller companies.

Large firms can benefit from economies of scale, scope of operation, specialization and stronger bargaining power. Consequently, smaller firms are 
less profitable than bigger firms. Companies that are relatively bigger have a tendency of having a greater level of diversification. Also, they face insolvency risk. Larger firms can also attract exemplary human resources that will significantly contribute to their financial performance. Companies that are bigger face smaller bankruptcy risk since they undertake massive diversification in comparison to smaller firms. Bankruptcy levels that are low assist companies that are big to finance their operations using more debts. Consequently, higher levels of debt lead to growth in profitability. Similarly, Wahome et al. (2015) studied the effects of risk and firm size decisions regarding capital structure among the Kenyan insurance companies. The study results indicated that the use of leverage in financing operations is apparent in big insurance firms as compared to those that are smaller, and this led to the growth in company profitability.

\section{Conclusion}

From the research findings, capital structure is vital to firm financial performance of the NSE listed nonfinancial companies. Firms should strive to increase their leverage since it has a statistically significant positive effect on the financial performance of the NSE listed nonfinancial companies. This is because from results of the study, these firms have higher debt amounts in their capital structure. This enables them obtain the tax benefits associated with debt. Consequently, the tax benefits leads to increased profitability and financial performance. Firm managers should seek to grow their firm sizes. This is because larger firms have consistently increased the use of debt in their capital structure.

\section{Recommendations}

The study findings have indicated that capital structure and financial performance have a positive relationship. The recommendation of the research is that company managers, other practitioners, and investors should focus on the need to make the right capital structure decisions that involves the use of increased debt levels that will help increase firm financial performance. Capital structure that is positive indicates that a firm is utilizing more debt than equity in its financing decisions. The implication of this is that in order to achieve growth and improved financial performance, firms should be highly leveraged. Regulators, policy makers, investors, and other practitioners should emphasize right capital structure choices and seek to grow firm size by increasing firms' total sales and total assets in order to maintain or improve financial performance. The indication from the study is that making the best decisions on firm financing can help firm managers take actions that are in harmony with shareholders interest, which is enhancing firm value. 


\section{References:}

1. Abbasi, A. \& Malik, Q.A. (2015). Firms' size moderating financial performance in growing firms: Empirical evidence from Pakistan. International Journal of Economics and Financial Issues, 5(2), 334339.

2. Abor, J. (2007). Debt policy and performance of SMEs. The Journal of Risk Finance, 8(4), 64- 379.

3. Baron, R. M. \& Kenny, D. A. (1986). The moderator-mediator variable distinction in social psychological research-conceptual, strategic, and statistical considerations. Journal of Personality and Social Psychology, 51(6), 1173-1182.

4. Cassar, G. \& Holmes, S. (2003). Capital structure and financing of SMEs: Australian evidence. Accounting and Finance, 43(2), 123147. doi: 10.1111/1467-629x.t01-1- 00085

5. Chittenden, F., Hall, G. \& Hutchinson, P. (2006). Small Firm Growth, Access to Capital Markets and Financial Structure: Review of Issues and an Empirical Investigation. Small Business Economics, 8, 59-67.

6. Cyril, U.M. (2016). The effect of capital structure on the financial performance of Nigerian quoted conglomerates.

European Journal of Accounting, Auditing and Finance Research 4 (6), 61-69.

7. Dancey, C. \& Reid, J. (2011). Statistics without maths for psychology $5^{\text {th }}$ Edition Prentice Hall London.

8. Dogan, D., Keskin, H., \& Akgun, A. E. (2016). Organizational aesthetic capability and firm product and process innovativeness. International Business Research, 9(7), 124.

9. Duffie, D. (2005). Valuation in Over-the-Counter Markets. doi: 10.3386/w12020

10. Fama, E. \& French, K. (2002). Testing Trade off and Pecking Order Predictions about Dividends and Debt. Review of Financial Studies 15, 1-37.

11. Gonenc, H. (2005). Comparison of debt financing between international and domestic firms: Evidence from Turkey, Germany and UK. International Journal of Managerial Finance, 1(1), 49-68

12. Harris, M. \& Raviv, A. (1999).Organization Design.SSRN Electronic Journal. doi:10.2139/ssrn. 174666.

13. Heshmati, A. \& Kim, H. (2011). The R\&D and productivity relationship of Korean listed firms. Journal of Productivity Analysis, 36(2), 125-142.

14. Kamuti, J.M. \& Omwenga, J. (2017). Factors influencing investment decisions in Nairobi Securities Exchange: a case of Dyer\& Blair 
Investment Bank Limited. International Academic Journal of Economics and Finance, 2(3), 1-15.

15. Kosimbei, G., Mwangi, L.W. \& Makau, W. (2014). Relationship between capital structure and performance non-financial companies listed in the Nairobi Securities Exchange, Kenya. Global Journal of Contemporary Research in Accounting, Auditing and Business Ethics, 1(2), 72-90.

16. Margaritis, D. \& Psillaki, M. (2007). Capital structure and firm efficiency. Journal of Business. 4(5), 15-27.

17. Modigliani, F. \& Miller, M. (1958). The cost of capital, corporation finance and the theory of investment. The American Economic Review, 48,261-297.

18. Muigai, R.G. \& Muriithi, J.G. (2017). The moderating effect of firm size on the relationship between capital structure and financial distress of non-financial companies listed in Kenya. Journal of Finance and Accounting, 5(4), 151-158.

19. Mwangi, J.M. (2016). Effect of Financial Structure on Financial Performance of Firms Listed at East Africa Securities Exchanges. Unpublished PhD thesis, Jomo Kenyatta University of Agriculture and Technology

20. Myers, S.C. (2001).Capital structure. Journal of Economic Perspectives, (15), 81-102.

21. Noreen, E. (2013). Are overhead costs strictly proportional to activity? Journal of Accounting and Economics, 17(1-2), 255-278.

22. Rajan, R.G. \& Zingales, L. (1995). What do we know about capital structure? Some evidence from international data. The Journal of Finance, 50(5), 1421-1460

23. Saeedi, A. \& Mahmoodi, I. (2011). Capital structure and firm performance: evidence from Iranian companies. International Research Journal of Finance and Economics, 70, 20-29.

24. Simerly, R.L. \& Li, M. (2000). Environmental dynamism, capital structure and performance: a theoretical integration and an empirical test. Strategic 1 Management Journal,21(1),3149. doi:10.1002/(sici)10970266(200001)21:13.3.co;k

25. Wahome, M.N., Muturi, W., \& Memba, F. (2015). The effects of firm size and risk on capital structure decisions of insurance industry in Kenya. International Journal of Scientific and Research Publications, 5, (8), 9-10.

26. Wu, A.D. \& Zumbo, B.D. (2008). Understanding and using mediators and moderators. Social Indicators Research, 87(3)367 